Reprod. Nutr. Dévelop., 1980, 20 (5 B), 1545-1562.

\title{
Neuroendocrinology of hyperphagias and obesities
}

\author{
par Jeanine LOUIS-SYLVESTRE \\ Laboratoire de Neurophysiologie sensorielle ef comportementale - E. P. H. E. \\ Collège de France, 11, place Marcelin-Berthelot, 75231 Paris Cedex 05, France.
}

Summary. The energy balance of an adult in stable conditions and eating ad libitum is in equilibrium over a long term as well as just during the $24 \mathrm{hrs}$ period. The activity phase of an individual may be diurnal or nocturnal, depending on the species ; this phase corresponds to relative hyperphagia and storage of the metabolites ingested but not used to cover continuous energy expenditure. During the resting phase, a compensatory process includes hypophagia and mobilization of the previously stored metabolites. The energy ballast is mainly represented by the adipose tissue, a store normally partly mobilized and reconstituted alternately. This metabolic pattern results from a neuroendocrine sequence whose partly known mechanism is the basis of the liporegulatory process. Obesity is caused by the alteration of this physiological mechanism regulating the adipose mass.

Two factors seem to be the key to the very complex syndrome of hypothalamic obesity. First, after lesion the feeding and metabolic light-dark cycle is abolished (the resting phase, hypophagia and lipolysis disappear) ; second, the cephalic phase of prandial events and particularly of insulin secretion is greatly enhanced. Works on this subject strongly suggest that hypothalamic lesion causes parasympathetic-sympathetic imbalance. In the normal resting animal, the stores are mobilized mainly by the sympathetic nervous system ; lower sympathetic activity in the lesioned animal would explain the absence of store mobilization. Increased parasympathetic activity would stimulate excessive preabsorptive insulin secretion under vagal control, producing the hyperinsulinemia characteristic of these animals.

Recessive genetic obesities are due to a simple molecular variation in the DNA sequence coding a peptide which may be an enzyme or a structure protein. The recent hypothesis proposing that the genetic deficiency of ob/ob mice is due to defective regulation of thyroiddependent $\left(\mathrm{Na}^{+} \mathrm{K}+\right)$-ATPase is satisfying because it explains most of the metabolic and behavioral deviations described in those animals, particularly hyperinsulinemia.

The mechanism eliciting dietetic obesity has not been extensively studied. A probable, as yet unconfirmed, hypothesis emphasizes a putative relation between food palatability and the amount of the insulin secreted reflexly in response to oral stimulation by that food.

Recent studies have reported an experimental model of hyperphagia related to stress (tail pinch).

Whatever the type of obesity, four symptoms are always present : hyperphagia, hyperinsulinism, insulin resistance and increased lipogenesis. Any one of these symptoms automatically causes the others which, in turn, acerbate it. Insulin resistance is the retroactive factor limiting the process.

\section{Introduction.}

The energy balance of the living organism has three parameters : energy loss in the form of heat and work, energy intake in the form of ingested nutriments and the 
energy mass which involves the structural material and the stores of the organism. In the adult, maintained in steady state conditions and eating ad libitum, this balance is equilibrated inasmuch as the third term is constant. Also, continuous metabolic expenditure and oxygen supply are associated with discontinuous energy supply in the form of meals. A study of the feeding pattern of many species has shown a dual periodicity (Duncan ef al., 1970 ; Le Magnen and Tallon, 1966 ; Natelson and Bonbright, 1978 ; Sanderson and VanderWeele, 1975 ; Wolf and Hainsworth, 1977). Considered in its prandial periodicity, feeding behavior is a factor of the glucoregulator mechanism. Food intake mechanisms, studied mainly in rats but confirmed in many species, have shown that humoral stimuli, reflecting a decrease in available energy, uncompensated for by the processes of internal regulation and acting on peripheric and/or central edoreceptors, trigger feeding behavior.

Moreover, the continuous, simultaneous recording of respiratory exchanges (oxygen intake, respiratory quotient) and feeding pattern has shown that the activity phase (diurnal or nocturnal according to the considered species) is related to a comparative hyperphagia and a fat storage (lipogenesis), making the energy balance positive. The resting phase is related to a strictly compensatory process with hypophagia and mobilization of the previously stored metabolites (lipolysis), causing the energy balance to be negative (Kimura, 1970 ; Le Magnen et al., 1973). This energy ballast is mainly represented by the adipose tissue, a store usually partly mobilized and reconstituted alternately. This metabolic pattern results from a neuroendocrine sequence whose partly known mechanism is fundamental to the lipo-regulation process. Obesity is caused by the alteration of this physiological mechanism regulating the adipose mass : the energy balance is not equilibrated and energy intake is higher than expenditure.

A summary of the data and the hypotheses concerning the liporegulatory process is thus a useful tool in interpreting our present knowledge of various types of experimental obesity.

In man as well as in animals (Aparicio et al., 1974 ; Carroll and Nestel, 1973 ; Gibson and Jarrett, 1972 ; Malherbe et al., 1969 ; Schlierf and Dorow, 1973 ; Sensi and Capani, 1976), the light/dark feeding pattern is concomitant with a metabolic periodicity. Thus, in the rat, basal insulinemia, insulinemic response to oral or intravenous glucose loads, and glucose tolerance are relatively higher at night than in the day and are accompanied by hyperphagia or weight gain (Louis-Sylvestre, 1978). On the contrary, in the day, a slight diabetic syndrome - lipolysis accompanied by hypoinsulinism, glucose intolerance and insulin resistance - represents the compensatory mechanism of noctural hyperphagia.

This metabolic cycle being well established and confirmed, some important questions remain to be answered. What stimulus causes the change in metabolic status? What is the target site of this stimulus and what efferent ways are used ? Finally, what in particular are the relations between the glucoregulatory system and feeding behavior on the one hand and the previously mentioned liporegulatory system on the other?

An appealing hypothesis has been proposed recently by Le Magnen (1980). Many experimental facts seem to indicate that the lateral hypothalamus (LH) is the 
important site of a group of structures involved solely in the food intake mechanism : the ventromedial hypothalamus (VMH) would be uniquely involved in alternately mobilizing and reconstituting the energy stores. In fact, any lesion of the LH temporarily suppresses spontaneous food intake (Anand and Brobeck, 1952 ; Grossman et al., 1978 ; Stricker, Swerdloff and Zigmond, 1978) and definitively prevents glucopeniainduced food intake when insulin or 2-deoxy-D-glucose (2 DG) is intravenously infused (Epstein and Teitelbaum, 1967 ; Nicolaïdis and Meile, 1972).

However, after the same lesion, the metabolic responses to the induced glucopenia remain (Epstein, Lee and Ku, 1965 ; Frohman and Nagai, 1976 ; Panerai ef al., 1975). An intrahypothalamic glucose injection inhibits the food intake elicited by systemic insulin injection but does not suppress the metabolic effects of that injection (Booth, 1968 ; Epstein, 1960 ; Stricker and Rowland, 1978).

Any VMH lesion causes a syndrome extending the nocturnal feeding and metabolic characteristics of the normal rat to the diurnal period (Le Magnen et al., 1973). After VMH lesion, food intake induced by general glucopenia increases (Epstein, 1960 ; King, Stamoutsos and Grossman, 1978 ; Panksepp and Nance, 1972), while metabolic response to 2DG is suppressed (Nishizawa and Bray, 1978). Glucose injected into the VMH does not inhibit food infake immediately; however, it does have a long-term effect (Epstein, 1960 ; Panksepp and Nance, 1972).

The model proposed (fig. 1) is the following : glucosensitive, insulinoindependent LH sites (probably those reported by Oomura, 1976) would respond to glucopenia by permitting the activation of the motor program of food intake.

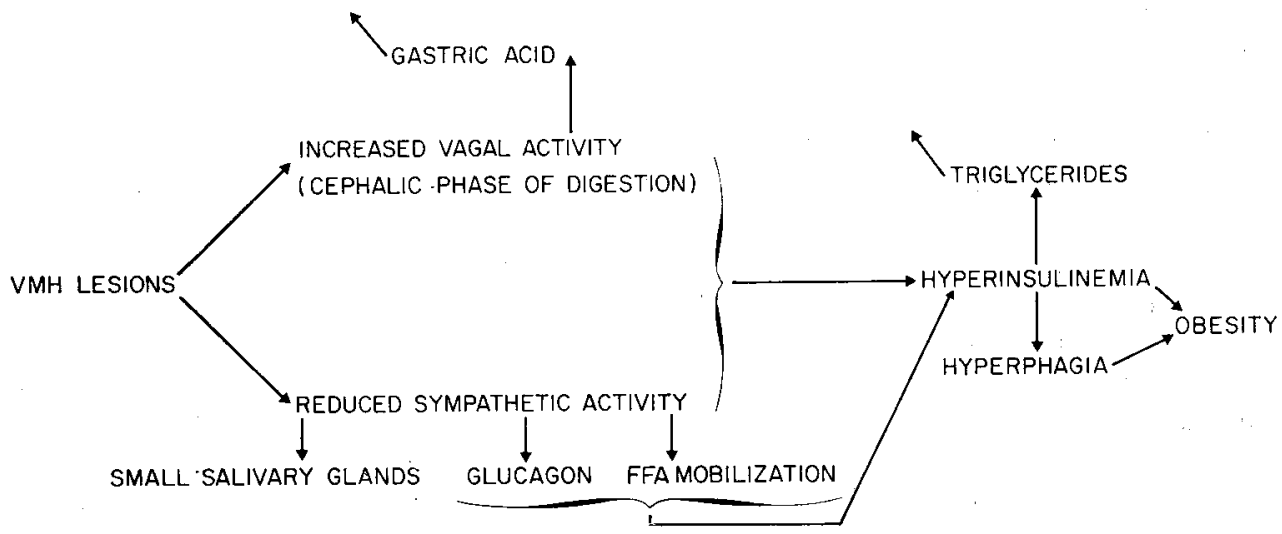

FIG. 1. - Diagram showing the results of parasympathetic and sympathetic imbalance after $V M H$ lesion. (From Bray and York, 1979).

The glucosensitive, insulinodependent VMH sites (confirmed by Oomura) would be activated when glucopenia is accompanied by insulinopenia or by lower insulin sensitivity.

The insulin sensitivity of insulinodependent cells, such as adipocytes (Kobayashi and Olefsky, 1978) and monocytes (Beck-Nielsen and Pedersen, 1978), is modulated by down-regulation. Hypoinsulinemia increases insulin sensitivity, while hyperinsulinemia results in insulin resistance. It may be hypothesized (and tentatively confirmed 
by work in progress) that insulin sensitivity at $\mathrm{VMH}$ insulinodependent sites is also under down-regulation.

Thus, at the onset of the diurnal period after several hours of nocturnal hyperinsulinemia, insulin sensitivity would be lower at the VMH gluco- and insulinodependent sites in the rat. Slight glucopenia would result in the well known metabolic response : mobilization of stores by sympathetic activation of glucagon-and adrenal noradrenalin secretion, direct sympathetic action on the adipose tissue and hypoinsulinism due to splanchnic action.

At the onset of the nociurnal period after several hours of hypoinsulinemia, these sites again bind more insulin, and less available glucose would be needed to activate them than to activate the $\mathrm{LH}$ sites controlling food intake.

When available glucose drops steadily during the day, the metabolic response would be induced before food intake and would thus prevent it ; at night, there would only be a feeding response.

The description and interpretation of various types of experimental obesity which follow will be based on the preceding explanation of the liporegulatory mechanism.

\section{Hypothalamic obesity}

The hypothalamic obesity seen after VMH lesioning has been obtained in many species such as rats, mice, pigs, geese, monkeys and cats but has been particularly studied in the first two. Several VMH lesion techniques using electrolytes (Hetherington and Ranson, 1940), radio frequencies (Hoebel, 1965), microsurgery of longitudinal fiber bundles at the paraventricular nucleus level (Albert ef al., 1971 ; Gold, 1970 ; Sclafani and Grossman, 1969) and in situ injection of aurothioglucose (Smith and Britt, 1971) and monosodium glutamate (Simson ef al., 1977) have been reported ; parenteral aurothioglucose injections were efficient in the mouse (Brecher and Waxler, 1949 ; Debons et al., 1962) but fatal in the rat.

Some studies have minutely reviewed the hypothalamic syndrome (Bray and Gallagher, 1975 ; Brobeck, 1946 ; Mayer and Thomas, 1967), and therefore only the important points will be mentioned here. The lesioned animal shows hyperphagia which may reach a 100 p. 100 increase immediately after lesioning and continue during the so-called dynamic phase when weight gain is rapid; food intake then decreases progressively until it reaches the presurgery level. During this static phase, weight gain slows down to zero and then stabilizes; its reduction by fasting or increase by force-feeding is followed by compensatory augmentation or reduction of food intake (Hoebel and Teitelbaum, 1966 ; Panksepp et al., 1975). The feeding pattern of the lesioned rat shows frequent large meals. Its important characteristic is the obliteration of the day-night difference, since hyperphagia is largely due to the increase of the amount of food ingested during the resting period, i. e. the day. The palatability of the food offered greatly affects the amount of food intake, lesioned rats being more sensitive than normal ones to the positive aspect of palatability while their response to negative palatability is unchanged (Corbit and Stellar, 1964 ; Ferguson and Keesey, 1975). The lesioned animal is traditionally described as incapable of working to obtain food (Teitelbaum, 1957). Recent studies have shown that when a lesioned rat 
is maintained at presurgical weight or less, if works as much as the normal rat ; the performance of the more obese rats is poorer (Sclafani and Kluge, 1974).

Lesioned rats become obese : weight gain is rapid (dynamic phase), then reaches a plateau determined by the diet, the imposed food pattern and the environment. This plateau particularly depends on the gravity of the syndrome : the level of hyperinsulinemia reached $48 \mathrm{hrs}$ after lesioning indicates the future degree of obesity (Hustvedt and Løvø, 1972). Weight increase is solely due to excess fat depots, the lean part of the carcass being slightly reduced as compared to that of normal rats. Moreover, when the animals are kept in conditions limiting the weight gain of the controls (tube-feeding, pair-feeding), an increase in adipose tissue is accompanied by a decrease in lean tissue. From an etiological viewpoint, this observation is important because it shows that obesity does not result entirely from hyperphagia (Rabin, 1974 ; Han, 1968).

Obesity has sometimes been partly attributed to decreased physical activity (Brooks, 1946) ; however, it should be noted that when activity loss and food intake are equal, normal rats do not become obese.

The obesity syndrome is characterized by an endocrine-metabolic profile whose main trait is hyperinsulinemia. Not only is basal insulinemia high (Hales and Kennedy, 1964 ; Han and Frohman, 1970) but the pre- and postabsorptive phases of prandial insulin secretion also increase (Steffens, 1969 ; Louis-Sylvestre, 1976) as well as the insulin response to an intravenous glucose load.

The etiology of hyperinsulinemia has been well studied in the lesioned rat. Experiments using force and pair-feeding have shown that hyperphagia does not cause hyperinsulinemia. However, if animals fasted for $24 \mathrm{hrs}$ are lesioned, insulinemia remains low until the first intake of food after surgery. The preabsorptive phase of insulin secretion is parficularly enhanced during that first intake (Louis-Sylvestre ef al., in press). This activation of the cephalic phase of insulin secretion could gradually induce basal hyperinsulinemia which increases progressively during the first post-surgical days (Han and Frohman, 1970).

The blood glucose level of lesioned animals is essentially normal (Frohman and Bernardis, 1971 ; Hales and Kennedy, 1964). The fact that hyperinsulinemia and normoglycemia are both observed raises questions regarding insulin resistance. The rapidity of either (i) ${ }^{14} \mathrm{C}$ incorporation from ${ }^{14} \mathrm{C}$-glucose into diaphragmatic glycogen or adipose tissue lipids (Hustvedt and Løvø, 1973) or (ii) the clearance of the same ${ }^{14} \mathrm{C}$ in the plasma has demonstrated that hypoinsulinemia in the lesioned rat is not the resulf of insulin resistance. The normal level of glycemia can probably be explained by increased gluconeogenesis (Goldman and Bernardis, 1975 ; Hongslo, Hustvedt and Løvø, 1974). The experiments on rapid ${ }^{14} \mathrm{C}$-glucose incorporation into adipose tissue lipids, previously mentioned, clearly show that lipogenesis is very active in the lesioned rat. On the contrary, the lipolysis induced by fasting or stimulated by adrenalin or glucagon is severely restricted (Haessler and Crawford, 1967 ; May and Beaton, 1966 ; Kasemari, Bernardis and Schnatz, 1972).

It is evident that the high circulating insulin level plays a major part in these metabolic disorders. But is it the only cause? Hypothalamic lesion also induced obesity in diabetic rats treated with insulin (Goldman ef al., 1972). A number of symptoms, 
such as hypoglucagonemia (Inoue, Campfield and Bray, 1977), reduced FFA mobilization under cold or exercise stress, and the disappearance of metabolic periodicity due to the extension of nocturnal phase conditions to the diurnal phase (Le Magnen et al., 1973), resemble the experimental facts described in the previous chapter. As stressed above, $\mathrm{VMH}$ lesion permits fat mobilization.

Ban (1975) showed that the VMH is a sympathetic center. The implication of the sympathetic nervous system in the hypothalamic obesity syndrome was first suggested by the small size of the salivary glands and a drop in glucagonemia (Inoue, Campfield and Bray, 1977). Finally, unilateral denervation of retroperitoneal fat in the normal animal and unilateral, ipsilateral VMH lesion elicit the same FFA mobilization disorder in the retroperitoneal adipose mass of the side concerned (Bray and Nishizawa, 1978). This strongly suggests the role of direct sympathetic innervation to adipose tissue from $\mathrm{VMH}$. The preponderance of the parasympathetic nervous system in the hypothalamic obesity syndrome is revealed in a number of ways. The lesioned rats show increased gastric volume and pepsin and acid secretion. This augmentation appears the first day after surgery and persists after food restriction (Ridley and Brooks, 1965). Vagotomy in lesioned rats makes obesity disappear (Powley and Opsahl, 1974). There is a significant correlation between the gastric acid and basal insulin levels (Inove and Bray, 1977). When the branches of the vagus nerve arriving in the pancreas are cut selectively, obesity is prevented in lesioned rats (Sawchenko ef al., 1977). It should be remembered that insulin secretion increases under vagal stimulation and that the cephalic phase of insulin secretion is abolished after vagotomy (Louis-Sylvestre, 1976). The hypothesis recently proposed by Bray and York (1979) and diagrammatically represented in figure 1 , emphasizes the imbalance between parasympathetic and sympathetic activity resulting from VMH.

The drop in sympathetic activity causes hypoglucagonemia, a decrease in lipolysis which, in turn, enhances hyperinsulinemia. The inhibition of diurnal lipolysis explains the disappearance of metabolic and feeding cyclicity.

Also, the augmentation of parasympathetic activity alone, affecting mainly the cephalic phase of insulin secretion, produces per se hyperinsulinemia (Powley, 1977).

\section{Genetic obesities}

Interest has been renewed recently in genetic obesities. In fact, many new data have been obtained, and the hypotheses formulated satisfactorily integrate these results.

The genefic obesity syndrome has been mainly described in rodents where numerous cases are found. Some are due to the mutation of a single dominant or recessive gene, while others are the result of polygenic mutation due to inbreeding. The present study is based on the obese mouse syndrome (ob/ob) resulting from the mutation of a single recessive gene on chromosome 6 (Coleman, 1978). The sequential appearance of the symptoms provides some conclusions as to their etiology. The first disorder observed after birth concerns thermogenesis. Decreased oxygen consumption and a drop in body temperature after exposure to cold become apparent between days 10 and 18 (Boissonneault et al., 1976 ; Kaplan and Leveille, 1973 ; Trayhurn, Thurlby 
and James, 1977). Adipocyte size - and body weight - increase after days 14 to 20 (Joosten and Van der Kroon, 1974 ; Kaplan, Trout and Leveille, 1976). Somewhat later, a slight hyperinsulinemia accompanied by hypoglycemia becomes apparent (Dubuc, 1976). While the first condition increases, there is a transition from hypoglycemia to hyperglycemia (Dubuc, 1976). After weaning, initial hypophagia (Up to days 28,35 ) is followed by galloping hyperphagia (Liu and Yin, 1974 ; Lin, Romsos and Leveille, 1977) with hyperplasia and hypertrophic adipocyte growth. Hyperphagia and hyperinsulinemia are progressively accompanied by glucose intolerance and insulin resisfance (Thurlby and Traihurn, 1978). This hyperphagia is characterized by the disappearance of nocturnal periodicity (Bayley et al., 1975) and increased efficiency of energy utilization (Bray and York, 1971). The reduction of physical activity or of heat loss probably contributes to increase this efficiency. Hyperphagia alone is unlikely to be responsible for the augmentation of the fat stores. In fact, caloric restriction does not prevent obesity (Chlouverakis, 1972), and hyperphagia appears in the young after a visible increase in adipocyte size and body weight.

The plasma insulin level, which increases at about the third neonatal week (Dubuc, 1976), is multiplied by four at week 6 and by fifty at 6 months. It decreases in old animals (Genuth, 1969 ; Mahler et al., 1976 ; Malaisse, Malaisse-Lagae and Coleman, 1968). Hyperinsulinemia, which appears after the early signs of obesity, is probably not the main or sole cause of it. In fact, treating obese mice with streptozotocin does not entirely prevent the depot of excessive stores (Batchelor et al., 1975). Cuendot ef al. (1975) found the plasma glucagon level normal or slightly high.

The mechanism of this hypersecretion of insulin, appearing before hyperphagia, has not been entirely elucidated. Beloff-Chain (1979) has recently suggested that a pituitary peptide, CLIP, a corticotropic peptide of the intermediary lobe, corresponding to the 18-39 fragment of ACTH and secreted in excess, would stimulate pancreatic insulin secretion in ob/ob mice. This hypothesis will be discussed later.

The effect of excessive gastric or intestinal peptide hormone stimulation has also been suggested (Best et al., 1974, 1977 ; Dockray, Best and Taylor, 1977). Finally, when the islets of normal mice are transplanted into ob/ob mice, obesity and diabetes abate (Strautz, 1970). The putative role of pancreatic polypeptide (PP) has also been indicated (Malaisse-Lagae et al., 1977).

Insulin resistance has often been demonstrated in ob/ob mice ; it is a secondary effect of hyperinsulinemia, and any treatment reducing hyperinsulinemia normalizes insulin sensitivity (Abraham and Beloff-Chain, 1971; Chlouverakis, 1972). This insensitivity appears after weaning and gradually increases until adulthood (Cuendot et al., 1976 ; Czech, Richardson and Smith, 1977 ; Lemarchand et al., 1977). The hyperglycemia observed in these mice is the evident result of insulin resistance.

Increases in body weight and adipose mass (measured directly) are correlated to the high rate of lipogenesis. Increased lipogenesis in the liver and the adipose tissue has been reported in vivo and in vitro using a large number of different isotopes (see review of Bray and York, 1979). This seems to be the normal response of these tissues to chronic insulin stimulation. The increase in adipose stores is performed by adipocyte hypertrophy and hyperplasia (Herberg ef al., 1974 ; Johnson and Hirsch, 1972 ; Kaplan, Trout and Leveille, 1976). It should be noted that hypertrophied adi- 
pocytes regain their normal size when transplanted into normal congeners (Ashwell and Meade, 1978). Lipectomy in obese animals is followed by the compensatory growth of other depots (Chlouverakis and Hojnicki, 1974). The adipose tissue of obese mice is less sensitive in vivo and in vitro to lipolytic agents than the same tissue of normal congeners. This deficit appears at week 4, increases as obesity augments and is not corrected by feeding restriction, fasting or normalization of the circulating insulin level. It could be either due to adipocyte-bound insulin (washing the adipocyte beforehand improves response) (Kissebah et al., 1975) or reflect lipolytic insensitivity (induced by catecholamines) to normal thyroid stimulation (Otto, Taylor and York, 1976 ; York, Otto and Taylor, 1978). This disorder could be explained by a deficiency of $\mathrm{Na}^{+} \mathrm{K}^{+}$-ATPase activated by thyroid hormones; its importance will be discussed later.

The complete or partial sterility of ob/ob mouse males and females has been attributed to a lack of gonadotropic stimulation (Swerdloff ef al., 1976, 1978). The pituitary of obese mice may be functionally immature (Nemeroff, Bisette and Kizer, 1978).

Some symptoms such as reduced metabolic rate, reduced body temperature, low resistance to cold and hypoactivity are correlated with thyroid disorders. However, this defective sensitivity to thyroid hormones is not general ; it is limited to thermogenesis. In this regard also the suspicious defect concerns $\mathrm{Na}^{+} \mathrm{K}^{+}$-ATPase.

Recessive genetic obesities result from a molecular change in the DNA sequence coding a single peptide which may be an enzyme or a structure protein. The hypothesis of Bray, York and Yukimura (1978) proposes that the genetic defect in ob/ob mice is deficient regulation of thyroid-dependent $\mathrm{Na}^{+} \mathrm{K}+$-ATPase; this theory is attractive because it explains most of the metabolic and behavioral symptoms described in these animals (fig. 2).

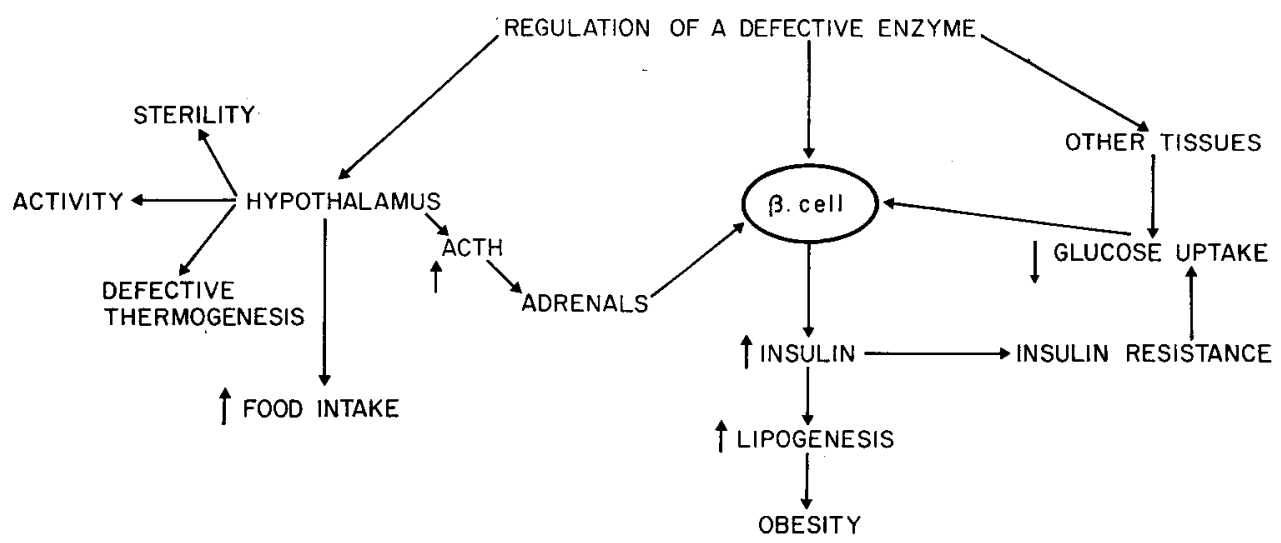

FIG. 2. - Diagram showing the possible role of defective enzyme regulation in the ob/ob mouse syndrome.

(From Bray and York, 1979.)

This enzyme defect may act independently at many sites; only two examples will be given here. It has been shown recently (Levin, Kasson and Driessen, 1978) that a 
reduction of $\mathrm{Na}^{+} \mathrm{K}+-\mathrm{ATPase}$ activity is associated with the insulin response elicited by glucose. This could explain the hyperinsulinemia.

The catecholamines have a major role in the hypothalamic control of food intake ; however, the presynaptic recovery of this transmitfer is a process which depends on the suspected enzyme (lwatsuka ef al., 1970). This would explain the hyperphagia.

Margules (1978) has also tried recently to explain the molecular mechanism by which a single genetic defect can cause such a large number of endocrine and behavioral abnormalities. He supposes that that gene originates the messenger RNA coding the glycosylated protein called proopiocortin. This substance, as shown in figure 3 ,

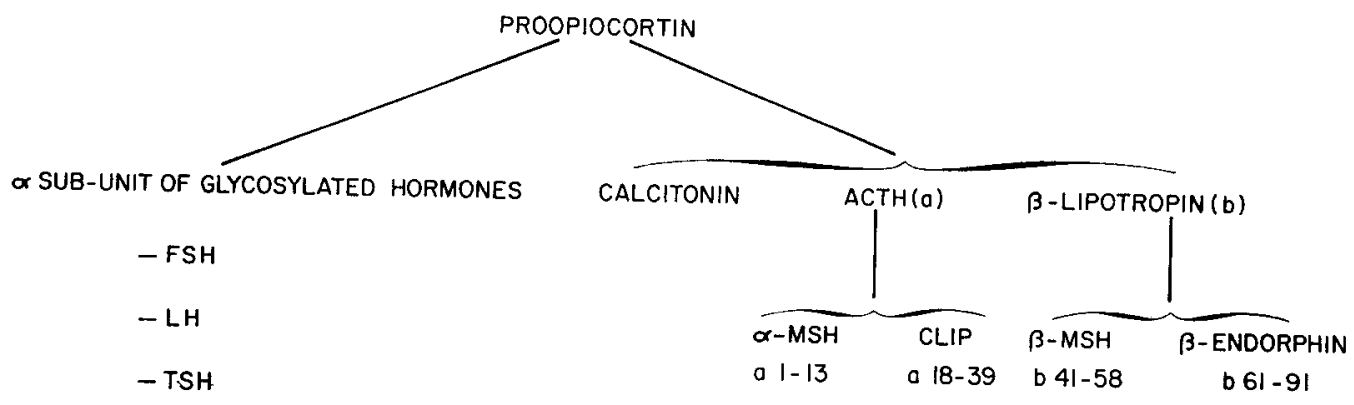

FIG. 3. - Proopiocortin (presumed by Margules, 1978, to be abnormal in genetic obesity) originates ten pifuitary subsfances or hormones.

originates ten pituitary substances and hormones which may secondarily affect other hormones. Thus, the adrenal cortex hormones would be affected by normal pituitary ACTH and the insulin by pituitary $\beta$-endorphin which is also abnormal.

\section{Nutritional obesities}

Early studies (Ingle, 1949) showed that restriction of activity and free access to a high calorie, palatable diet caused substantial weight gain in normal rats. Many later experiments (Barboriak et al., 1958 ; Fenton and Carr, 1951 ; Mickelsen, Takahashi and Craig, 1955 ; Peckham, Entenman and Carrol, 1962 ; Schemmel, Mickelsen and Fisher, 1973) have shown that a high-fat diet can cause obesity. The animal usually compensates for the increased caloric density of the high-fat diet by decreasing the amount of food intake ; however, this adjustment is not perfect and caloric intake remains high (Lyon, Dowling and Fenton, 1953; Schemmel et al., 1970a). Hyperphagia and weight gain depend not only on the lipid level of the dief but also on animal age and strain. Thus, while Osborne-Mendel rats kept on a 60 p. 100 lipid diet ate 20 p. 100 of additional calories, S5B/PI rats in the same conditions took only 5 p. 100 (Schemmel et al., 1970a). Although this obesity may be obtained at any age, the effect of the high-fat diet is more marked in young animals (Schemmel et al., 1969, 1970b). Sex differences in response to the high-fat diet are more evident in fat store distribution than in the total percentage of adipose tissue (Schemmel et al., 1969, 1970b).

Obesity caused by carbohydrates has been the object of a recent study by Kanarek and Hirsch (1977). These authors showed that the caloric intake of rats eating their usual diet and a carbohydrate solution (glucose, saccharose, fructose or maltose) 
increased by about 20 p. 100 . Whatever solution was given ( 16 or 32 p. 100 glucose; 32 or 64 p. 100 saccharose), the volume ingested was such that the animals received, in the form of carbohydrates, the same percentage of their total energy intake (5565 p. 100); protein and lipid intakes were thus relatively constant. It is remarkable that, in those conditions, protein intake represented about 10 p. 100 of the daily caloric intake, which corresponds exactly to the percentage ingested by animals choosing their diet composition ad libitum (Collier, Leshner and Squibb, 1969).

Free access to several very palatable foods may induce obesity in the normal animal (Sclafani and Springer, 1976 ; Rolls and Rowe, 1977). Adult rats offered a variety of high-calorie foods (cheese, salami, condensed milk, cookies, chocolate), as well as their usual diet, gained $21 / 2$ times more weight in 60 days than the control rats offered only their usual laboratory chow (Sclafani and Springer, 1976).

Carcass analysis showed that the two groups of rats did not differ in body or femur length but in the size of the adipose depots (Rolls and Rowe, 1977). Physical exercise was slightly effective in controlling the weight gain of males eating the " cafeteria » diet ; isolation, however, increased it. At present, it is difficult to determine the respective roles, in this hyperphagia, of food palatability and variety. Variety itself is certainly important. Le Magnen (1960) showed that rats trained to eat their food in one single monotonous meal of $2 \mathrm{hrs}$ and also familiar with four different varieties of the same food, ate more when the four varieties were offered successively or simultaneously during the same meal.

A controversial point between the two research teams studying this dietary obesity is of special interest. The «black hooded» rats studied by one group showed permanent obesity ; when they were again fed their usual diet, their weight did not return to that of the controls (Roll and Rowe, 1977). Moreover, weight loss due to dietary restriction was followed by a rapid return to obesity once they began eating the usual diet. The CFE rats of the second research group lost weight as soon as their usual diet replaced the "cafeteria » diet (Sclafani and Springer, 1976). The two research teams used similar experimental procedures but different strains of rats.

The measurement of energy balance during induced hyperphagia in SpragueDawley rats showed the quantitative importance of thermogenesis, induced by the diet, in that balance. As cold-induced thermogenesis, diet-induced thermogenesis includes changes in sympathetic system activity and in the brown adipose tissue. In fact, in animals with induced obesity, a noradrenalin injection has a greater effect and the hypertrophy of brown adipose tissue weight is not related to lipid depot in that tissue (Rothwell and Stock, 1979). This suggests that this tissue could be a determining factor in the change in metabolic efficiency and probable resistance to obesity.

The contribution of adipose brown tissue to total heat production has not yet been quantified, but there is a close correlation between oxygen production during the resting period in rats with induced obesity and the interscapulary mass of brown adipose tissue (Rothwell and Stock, 1979). This does not exclude other factors in the metabolic response to hyperphagia, such as thyroid hormone action or the reinforced lipolytic effect of noradrenalin on white adipose tissue. After a while, the minimal increase of daily caloric intake produces a large energy increment stored in the form of adipose tissue. The works mentioned previously showed that a small, constantly 
positive error in energy balance may occur in several ways in the normal, neurologically intact animal. The mechanism inducing dietary obesity has not yet been studied. A probable hypothesis, which is being confirmed, is a possible relation between food palatability and the importance of the preabsorptive insulin secretion reflex due to oral stimulation by the food (cephalic phase of insulin secretion).

We have no data yet on metabolic or endocrine changes, such as endocrine action or a probable basal hyperinsulinemia caused by the postulated increase of insulin response to intake.

\section{Stress obesity}

In the last 5 years, the animal model has been used to study obesity as related to stress. A non-specific tail pinch without visible pain elicits food intake in the surfeited rat (Rowland and Antelman, 1975). Hyperphagia caused by stress is the manifestation, directed towards the food, of an increased response to environmental stimulation. In fact, the behavior observed during the above treatment is not limited to food intake ; it can be, for example, maternal or sexual, depending on what is presented to the animal. This behavior is normally accomplished and occurred after a short latency. Six daily sessions of the treatment, lasting 10 to $15 \mathrm{~min}$ each, cause food intake to increase about 130 p. 100 . After the treatment is stopped, the animal returns gradually to its normal weight, although food intake during the first 2 to 3 days is zero. Some experiments, such as lesioning of the nigrostriatal bundle, pimozide injections or dopamine receptor blockade, have demonstrated that the dopaminergic nigrostriatal system is essential in that phenomenon (Antelman et al., 1975). This result resembles that of Wise ef al. (1978) who showed in the starved animal that pimozide selectively blocked the reward value of food intake.

It is inferesting to note that stress suppresses anorexia caused by amphetamines (which interfere with dopaminergic activity), but not anorexia elicited by fenfluramine which has a serotoninergic action (Antelman ef al., 1978).

\section{Conclusion.}

As shown in the first part of this paper, the VMH governs a neuroendocrine mechanism which corrects and limits the repletion of adipose stores. This pattern, usually observed when the organism is resting, includes (i) activation of store mobilization by direct sympathetic action on adipose tissue and indirect action on the $\alpha$-cells and adrenals, and (ii) limitation of storage by inhibitory splanchnic action on the $\beta$-cells (hypoinsulinemia).

The main cause of the hypothalamic syndrome is the impairment of these two processes by ventromedian destruction.

The main cause of the genetic obesity syndrome is probably the separate impairment, in this case, of the same two processes because the identical defective enzyme inhibits lipolysis and increases insulin secretion.

Nutritional and stress obesities apparently have different etiologies. Hyperphagia seems to be the principal cause of the different symptoms of these syndromes. 
From these various major causes, a series of positive or negative retroactions between the four main symptoms (hyperinsulinemia, hyperphagia, lipogenesis and insulin resistance) explains the progress and the limitation of the syndromes discussed. Thus, hyperinsulinosecretion increases lipogenesis (A) (fig. 4 ; Le Magnen, 1980) but

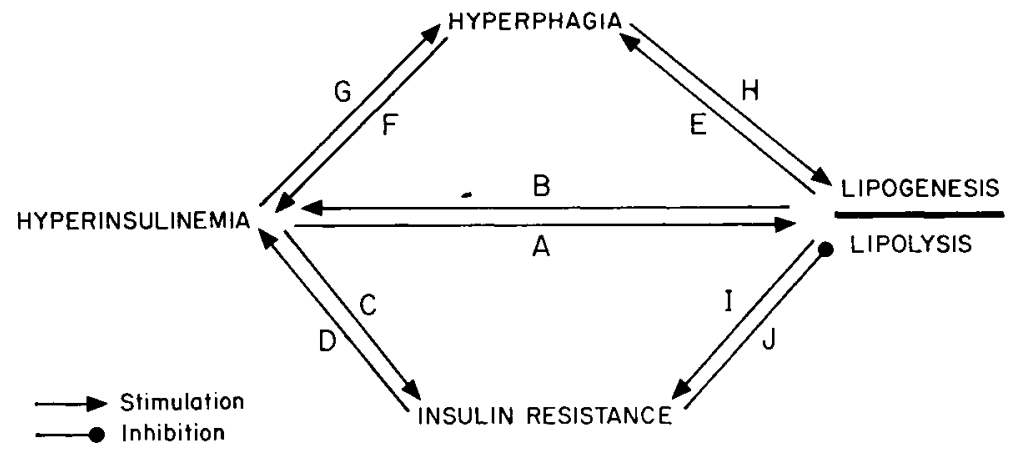

FIG. 4. - Positive and negative retroactions between the four major symptoms of obesity.

(From Le Magnen, 1980.)

rapid renewal of free fatty acids reinforces hyperinsulinemia (B). The latter causes insulin resistance (C) which, due to glucose intolerance and induced hyperglycemia, is also reinforced (D). Increased lipogenesis and hyperinsulinemia increase hyperphagia (E, F). Hyperphagia augments hyperinsulinemia (G) and enhances lipogenesis $(H)$. The insulin resistance caused by hyperinsulinemia and adipocyte hypertrophy (I) forms the only negative retroaction which determines the new static level of obesity.

Journées Ingestion-Digestion-Absorption de I'Association française de Nutrition Paris, 15-16 novembre 1979.

Résumé. Chez l'adulte, en conditions stables, disposant de nourrifure ad libitum, la balance énergétique est en équilibre aussi bien à long terme qu'à l'échelle du nycthémère. A la phase d'activité de l'individu (diurne ou nocturne, selon les espèces) correspondent une hyperphagie relative et une mise en réserve des métabolites ingérés non utilisés à la couverture de la dépense métabolique continue. A la phase de repos correspond un phénomène exactement compensateur : une hypophagie et une mobilisation des métabolites précédemment $m i s$ en réserve. Ce ballast énergétique est principalement représenté par le tissu adipeux, réserve normalement et alternativement mobilisée en partie, puis restaurée. Cette séquence métabolique est le résultat d'une séquence neuroendocrinienne dont le mécanisme, en partie connu, est la base du processus de liporégulation. L'obésité est le résultat de l'altération de ce mécanisme physiologique de régulation de la masse adipeuse.

Deux facteurs semblent être la clef du syndrome très complexe de l'obésité hypothalamique. Après lésion, on constate l'effacement du cycle nycthéméral alimentaire et métabolique par la disparition de l'hypophagie et de la lipolyse de la phase de repos; on constate également l'exagération de la phase céphalique des événements prandiaux (en particulier de la sécrétion insulinique). Des travaux convergents suggèrent fortement que la lésion hypothalamique crée un déséquilibre parasympathique-sympathique. Chez l'animal normal, pendant la période de repos, la mobilisation des réserves est principalement sous contrôle sympathique. La baisse de l'activité sympathique chez l'animal lésé expliquerait 
l'absence de mobilisation des réserves. L'augmentation de l'activité parasympathique expliquerait que soit exacerbée la sécrétion préabsorptive d'insuline, sous contrôle vagal, et que soit ainsi créée l'hyperinsulinémie caractéristique de ces animaux. Les obésités génétiques à transmission récessive sont dues à une simple variation moléculaire, dans la séquence de l'ADN qui code un peptide, pouvant être une enzyme ou une protéine de structure. L'hypothèse récente selon laquelle le défaut génétique des souris ob/ob serait une régulation défectueuse de l'enzyme « $\mathrm{Na}^{+} \mathrm{K}+$ ATPase thyroïd-dependent » est satisfaisante parce qu'elle explique la plupart des déviations métaboliques et comportementales décrites chez ces animaux, et tout particulièrement l'hyperinsulinémie.

Le mécanisme d'induction de l'obésité diététique a été peu étudié. Une hypothèse vraisemblable, non encore confirmée, met l'accent sur une relation possible entre palatabilité de l'aliment et importance de la sécrétion réflexe d'insuline due aux stimulations orales par cet aliment.

Des travaux récents ont décrit un modèle expérimental d'hyperphagie liée au stress (tail pinch).

Quelle que soit l'obésité considérée, quatre symptômes sont toujours constatés : hyperphagie, hyperinsulinisme et résistance à l'insuline, enfin, lipogenèse accrue. Un quelconque de ces symptômes entraîne obligatoirement les autres qui, en retour, l'aggravent. La résistance à l'insuline constitue alors le facteur de rétroaction qui limite le phénomène.

\section{References}

ABRAHAM R. R., BELOFF-CHAIN A., 1971. Hormonal control of intermediary metabolism in obesehyperglycemic mice. I. The sensitivity and response to insulin in adipose tissue and muscle in vitro. Diabetes, 20, 522-524.

ALBERT D. J., STORLIEN L. H., ALBERT J. G., MAH C. J., 1971. Obesity following disturbance of the ventromedial hypothalamus : a comparison of lesions, lateral cuts and anterior cuts. Physiol. Behav., 7, 135-141.

ANAND B. K., BROBECK J. R., 1952. Hypothalamic control of food intake in rats and cats. Yale J. biol. Med., 24, 123-146.

ANTELMAN S. M., CAGGIULA A. R., BLACK C. A., EDWARDS D. J., 1978. Stress reverses the anorexia induced by amphetamine and methyl-phenidate but not fenfluramine. Brain Res., 143, 580-585.

ANTELMAN S. M., SZECHTMAN H., CHIN P., FISHER A. E., 1975. Tail pinch induced eating, gnawing and licking behavior in rat : dependence on the nigrostriatal dopamine system. Brain Res., 99, 319-338.

APARICIO N. J., PUCHULU F. E., GAGLIARDINO J. J., RUIZ M., LLORENS J. M., RUIZ J., LAMAS A., DE MIGUEL R., 1974. Circadian variation of the blood glucose, plasma insulin and human growth hormone levels in response to an oral glucose load in normal subjects. Diabetes, 23 , 132-137.

ASHWELL M., MEADE C. J., 1978. Obesity : do fat cells from genetically obese mice (C 57 BL/6J ob/ob) have an innate capacity for increased fat storage? Diabefologia, 15, 465-470.

BAILEY C. J., ATKINS T. W., CONNER M. J., MANLEY C. G., MATTY A. J., 1975. Diurnal variations of food consumption, plasma glucose and plasma insulin in lean and obese-hyperglycemic mice. Hormones, 6, 380-386.

BAN T., 1975. Fiber connections in the hypothalamus and some autonomic functions : central neural control of eating and obesity. Pharmacol. biochem. Behav., 3 (suppl. 1), 3-13.

BARBORIAK J. J., KREHLW. A., COWGILL G. R., WHEDON A. D., 1958. Influence of high-fat diets on growth and development of obesity in the albino rat. J. Nutr., 64, 241-249.

BATCHELOR B. R., STERN J. S., JOHNSON P. R., MAHLER R. J., 1975. Effects of streptozotocin on glucose metabolism, insulin response and adiposity of ob/ob mice. Metabolism, 24, 77-91.

BECK-NIELSEN H., PEDERSEN O., 1978. Diurnal variation in insulin binding of human monocytes. J. clin. Endocrinol. Metab., 47, 385-390. 
BELOFF-CHAIN A., 1979. Abnormal function of the endocrine pancreas in genetic and experimentallyinduced obesity in rodents. In FESTING M., Genetic models of obesity in laboratory animals. Macmillan, London.

BEST L., ATKINS T., BAILEY C., FLATT P., NEWTON D., MATTY A., 1977. Increased activity of entero-insular axis in obese-hyperglycemic mice (ob/ob). J. Endocrinol., 72, 44P.

BEST L., ATKINS T., MATTY A., 1974. Effect of pancreozymin, secretin and gastrin pentapeptide on insulin secretion from isolated islets of Langerhans of normal and obese hyperglycemic mice. J. Endocrinol., 61, 69-70.

BOISSONNEAULT G. A., HORNSHUH M. J., SIMONS J. W., ROMSOS D. R., LEVEILLE G. A., 1976. Oxygen consumption of lean and obese (ob/ob) mice from birth to 16 weeks of age. Fed. Proc., 36, 1150.

BOOTH D. A., 1968. Effects of intrahypothalamic glucose injection on eating and drinking elicited by insulin. J. comp. physiol. Psychol., 65, 13-16.

BRAY G. A., GALLAGHER T. F., 1975. Manifestations of hypothalamic obesity in man. A comprehensive investigation of 8 patients and a review of the literature. Medicine, 54, 301-330.

BRAY G. A., NISHIZAWA Y., 1978. Ventromedial hypothalamus modulates fat mobilization during fasting. Noture, 274, 900-902.

BRAY G. A., YORK D. A., 1971. Genetically transmitted obesity in rodents. Physiol. Rev., 51, 598-646.

BRAY G. A., YORK D. A., 1979. Hypothalamic and genetic obesity in experimental animals : an autonomic and endocrine hypothesis. Physiol. Rev., 59, 719-809.

BRAY G. A., YORK D. A., YUKIMURA Y., 1978. Activity of $\left(\mathrm{Na}^{+}+\mathrm{K}^{+}\right)$-ATPase in the liver of animals with experimental obesity. Life Sci., 22, 1637-1642.

BRECHER G., WAXLER S. H., 1949. Obesity in albino mice due to single injections of gold thioglucose. Proc. Soc. exp. Biol. Med., 70, 498-501.

BROBECK J. R., 1946. Mechanism of development of obesity in animals with hypothalamic lesions. Physiol. Rev., 26, 541-559.

BROOKS C. M., 1946. The relative importance of changes in activity in development of experimentally produced obesity in the rat. Am. J. Physiol., 147, 708-716.

CARROLL K. F., NESTEL P. J., 1973. Diurnal variation in glucose tolerance and in insulin secretion in man. Diabetes, 22 333-348.

CHLOUVERAKIS C., 1972. Effect of caloric restriction on body weight loss and fat utilization in obesehyperglycemic mice (ob/ob). Metabolism, 21, 10-17.

CHLOUVERAKIS C., HOJNICKI D., 1974. Lipectomy in obese-hyperglycemic mice (ob/ob). Metabolism, 23, 133-137.

COLEMAN D. L., 1978. Genetics of obesity in rodents, 142-152. In BRAY G. A., Recent advances in obesity research II. Newman, London.

COLLIER G., LESHNER A. I., SQUIBB R. L., 1969. Self-selection of nafural and purified dietary protein. Physiol. Behav., 4, 83-86.

CORBIT J. D., STELLAR E., 1964. Palatability, food intake and obesity in normal and hyperphagic rats. J. comp. physiol. Psychol., 58, 63-67.

CUENDOT G. S., LOTEN E. G., CAMERON D. P., RENOLD A. E., MARLISS E. B., 1975. Hormonesubstrate responses to total fasting in lean and obese mice. Am. J. Physiol., 228, 276-283.

CUENDOT G. S., LOTEN E. G., JEANRENAUD B., RENOLD A. E., 1976. Decreased basal, noninsulin stimulated glucose uptake and metabolism by skeletal, soleus muscle isolated from obese hyperglycemic (ob/ob) mice. J. clin. Invest., 58, 1078-1088.

CZECH M., RICHARDSON D., SMITH C., 1977. Biochemical basis of fat cell resistance in obese rodents and man. Metabolism, 26, 1057-1078.

DEBONS A. F., SILVER F. L., CRONKITE E. P., JOHNSON H. A., BRECHER G., TENZER D., SCHWARTZ I. L., 1962. Localization of gold in mouse brain in relation to gold thioglucose obesity. Am. J. Physiol., 202, 743-750.

DOCKRAY G. J., BEST L., TAYLOR I. L., 1977. Immunochemical characterization of gastrin in pancreatic islets of normal and genetically obese mice. J. Endocrinol., 72, 143-151.

DUBUC P., 1976. The development of obesity, hyperinsulinemia and hyperglycemia in ob/ob mice. Metabolism, 25, 1567-1574.

DUNCAN I. J., HORNE A. R., HUGHES B. O., WOOD-GUSH D. G., 1970. The pattern of food intake in female brown leghorn fowls as recorded in a skinner box. Anim. Behav., 18, 245-255. 
EPSTEIN A. N., 1960. Reciprocal changes in feeding behavior produced by intrahypothalamic chemical injections. Am. J. Physiol., 199, 969-974.

EPSTEIN A. N., LEE S., KU A., 1965. Identical blood sugar response to insulin in normal and recovered lateral rats. 23rd Int. Congr. physiol. Sci., Tokyo, Abstr. 1130.

EPSTEIN A. N., TEITELBAUM P., 1967. Specific loss of the hypoglycemic control of feeding in recovered rats. Am. J. Physiol., 213, 1159-1167.

FENTON P. T., CARR C., 1951. The nutrition of the mouse : response of four strains to diets differing in fat content. J. Nutr., 45, 225-234.

FERGUSON N. B. L., KEESEY R. E., 1975. Effect of quinine-adulterated diet upon body weight maintenance in male rats with ventromedial hypothalamic lesions. J. comp. physiol. Psychol., 89, 478488.

FROHMAN L. A., BERNARDIS L. L., 1971. Effect of hypothalamic stimulation on plasma glucose, insulin and glucagon levels. Am. J. Physiol., 221, 1596-1603.

FROHMAN L. A., GOLDMAN J. K., BERNARDIS L. L., 1972. Metabolism of intravenously injected ${ }^{14} \mathrm{C}$-glucose in weanling rats with hypothalamic obesity. Metabolism, 21, 799-805.

FROHMAN L. A., NAGAI K., 1976. Central nervous system-mediated stimulation of glucagon secretion in the dog following 2-deoxy-glucose. Metabolism, 25 (suppl. 1), 1449-1452.

GENUTH S. M., 1969. Hyperinsulinism in mice with genetically determined obesity. Endocrinology, 84, 386-391.

GIBSON T., JARRETT R. J., 1972. Diurnal variation in insulin sensitivity. Lancet, II, 947-948.

GOLD R. M., 1970. Hypothalamic hyperphagia produced by parasagittal knife cuts. Physiol. Behav., 5, 23-25.

GOLDMAN J. K., BERNARDIS L. L., 1975. Gluconeogenesis in weanling rats with hypothalamic obesity. Horm. Metab. Res., 7, 148-152.

GOLDMAN J. K., SCHNATZ J. D., BERNARDIS L. L., FROHMAN L. A., 1972. Effects of ventromedial hypothalamic destruction in rats with preexisting streptozotocin-induced diabetes. Metabolism, 21, 132-136.

GROSSMAN S. P., DALEY D., HALARIS A. E., COLLIER T., ROUTTENBERG A., 1978. Aphagia and adipsia after preferential destruction of nerve cell bodies in hypothalamus. Science, 202, 537539.

HALES C. N., KENNEDY G. C., 1964. Plasma glucose, non-esterified fatty acids and insulin concentrations in hypothalamic-hyperphagic rats. Biochem. J., 90, 620-624.

HAN P. W., 1968. Energy metabolism of tube-fed hypophysectomized rats bearing hypothalamic lesions. Am. J. Physiol., 215, 1343-1350.

HAN P. W., FROHMAN L. A., 1970. Hyperinsulinemia in tube-fed hypophysectomized rats bearing hypothalamic lesions. Am. J. Physiol., 219, 1632-1636.

HETHERINGTON A. W., RANSON S. W., 1940. Hypothalamic lesions and adiposity in the rat. Anat. Rec., 78, 149-172.

HERBERG L., DOEPPEN W., MAJOR E., GRIES F. A., 1974. Dietary induced hypertrophic-hyperplastic obesity in mice. J. Lipid Res., 6, 580-585.

HAESSLER H. A., CRAWFORD J. D., 1967. Fatty acid composition and metabolic activity of depot fat in experimental obesity. Am. J. Physiol., 213, 255-261.

HOEBEL B. G., 1965. Hypothalamic lesions by electrocauterization : desinhibition of feeding and selfstimulation. Science, 149, 452-453.

HOEBEL B., TEITELBAUM P., 1966. Weight regulation in normal and hypothalamic hyperphagic rats. J. comp. physiol. Psychol., 61, 189-193.

HONGSLO C. F., HUSTVEDT B. E., LØVØ A., 1974. Insulin sensitivity in rats with ventromedial hypothalamic lesions. Acta physiol. scand., 90, 757-763.

HUSTVEDT B. E., LØVØ A., 1972. Correlation between hyperinsulinemia and hyperphagia in rats with ventromedial hypothalamic lesions. Acta physiol. scand., 84, 29-33.

HUSTVEDT B. E., LØVØ A., 1973. Rapid effect of ventromedial hypothalamic lesions on lipogenesis in rats. Acta physiol. scand., 87, 28A-29A.

INGLE D. J., 1949. A simple mean of producing obesity in the rat. Proc. Soc. exp. Biol. Med., 72, 604-605.

INOUE S., BRAY G. A., 1977. The effect by subdiaphragmatic vagotomy in rats with ventromedial hypothalamic obesity. Endocrinology, 100, 108-114.

INOUE S., CAMPFIELD L. A., BRAY G. A., 1977. Comparison of metabolic alterations in hypothalamic and high fat diet-induced obesity. Am. J. Physiol., 233, R162-168. 
IWATSUKA H., MATSUO T., SHINO A., SUZUOKI Z., 1970. Metabolic disturbances of KK mice in chemical diabetes. J. Takeda Res. Lab., 29, 685-692.

JOHNSON P. R., HIRSCH J., 1972. Cellularity of adipose depots in six strains of genetically obese mice. J. Lipid Res., 13, 2-11.

JOOSTEN H., VAN DER KROON P. H. W., 1974. Enlargement of epididymal adipocytes in relation to hyperinsulinemia in obese hyperglycemia mice (ob/ob). Metabolism, 23, 59-66.

KANAREK R. B., HIRSCH E., 1977. Dietary induced overeating in experimental animals. Fed. Proc., 36, 154-158.

KAPLAN M. L., LEVEILLE G. A., 1973. Obesity : prediction of preobesity among progeny from crosses of ob/+ mice. Proc. Soc. exp. Biol. Med., 143, 925-928.

KAPLAN M. L., TROUT J. R., LEVEILLE G. A., 1976. Adipocyte size distribution in ob/ob mice during preobese and obese phases of development. Proc. Soc. exp. Biol. Med., 153, 476-482.

KASEMARI S. L., BERNARDIS L. L., SCHNATZ J. D., 1972. Fat mobilization in adipose tissue of weanling rats with hypothalamic obesity. Hormones, 3, 97-104.

KIMURA T., 1970. Periodicity of food intake and lipogenesis in rats subjected to two different feeding plans. J. Nutr., 100, 691-697.

KING B. M., STAMOUTSOS B. A., GROSSMAN S. P., 1978. Delayed response to 2-deoxy-D-glucose in hypothalamic obese rats. Pharmac. biochem. Behav., 8, 259-262.

KISSEBAH A. H., CLARKE P. V., VYDELINGUM N., HOPE-GILL H. F., TULLOCH B. R., FRASER T. R., 1975. Mechanism of insulin resistance associated with obesity. in HOWARD A. N. Recent advances in obesity research, I. Newman, London.

KOBAYASHI M., OLEFSKY J. M., 1978. Effect of experimental hyperinsulinemia of insulin binding and glucose transport in isolated rat adipocyłes. Am. J. Physiol., 235, E53-E62.

LE MAGNEN J., 1960. Effet d'une pluralité de stimuli alimentaires sur le déterminisme quantitatif de Y'ingestion. Arch. Sci. physiol., 14, 411-419.

LE MAGNEN J., 1980. Energy balance, food intake and obesity. In R. ASSAN, J. GIRARD, E. B., MARLISS. Diabetes mellitus : Pathophysiologic approach to clinical practise. John Wiley \& Sons (NY) (in press).

LE MAGNEN J., DEVOS M., GAUDILLIERE J. P., LOUIS-SYLVESTRE J., TALLON S., 1973. Role of a lipostatic mechanism in regulation by feeding of energy balance in rats. J. comp. physiol. Psychol., 84, 1-23.

LE MAGNEN J., TALLON S., 1966. La périodicité spontanée de la prise d'aliments ad libitum du rat blanc. J. Physiol. Paris, 58, 323-349.

LE MARCHAND Y., LOTEN E. G., ASSIMACOPOULOS-JEANNET F., FORGUE M. E., FREYCHET B., JEANRENAUD B., 1977. Effect of fasting and streptozotocin in the obese hyperglycemic (ob/ob) mouse. Apparent lack of a direct relationship between insulin binding and insulin effects. Diabetes, 26, 582-590.

LEVIN S. R., KASSON B. G., DRIESSEN J. F., 1978. Adenosine triphosphate of rat pancreatic islets. Comparison with those of rat kidney. J. clin. Invest., 62, 692-701.

LIN P. Y., ROMSOS D., LEVEILLE G., 1977. Food intake, body weight gain and body composition of young obese (ob/ob) mice. J. Nutr., 107, 1715-1723.

LIU C. M., YIN T. H., 1974. Caloric compensation to gastric loads in rats with hypothalamic hyperphagia. Physiol. Behav., 13, 231-238.

LOUIS-SYLVESTRE J., 1976. Preabsorptive insulin release and hypoglycemia in rats. Am. J. Physiol., 230, 56-60.

LOUIS-SYLVESTRE J., LARUE-ACHAGIOTIS C., LE MAGNEN J. Oral induction of the insulin hyperresponsiveness in rats with ventromedial hypothalamic lesions (submitted for publication).

LOUIS-SYLVESTRE J., 1978. Feeding and metabolic patterns in rats with truncular vagotomy or with transplanted $\beta$ cells. Am. J. Physiol., 235, E 119-E 125.

LYON J. B., DOWLING M. T., FENTON P. F., 1953. Studies on obesity. II. Food intake and oxygen consumption. J. Nutr., 51, 65-70.

MAHLER R., DUBUC P., MOBLEY P., ENSINCK J., 1976. Glucagon and insulin interrelationships in the obese-hyperglycemic mouse. Horm. Metab. Res., 8, 79-80.

MALAISSE W. J., MALAISSE-LAGAE F., COLEMAN D. L., 1968. Insulin secretion in experimental obesity. Mefabolism, 17, 802-807. 
MALAISSE-LAGAE F., CARPENTIER J. L., PATEL Y. C., MALAISSE W. J., ORCI L., 1977. Pancreatic polypeptide : a possible role in the regulation of food intake in the mouse : hypothesis. Experientia, 33, 915-917.

MALHERBE G., DE GASPARO M., HERTOGH R., HOET J. J., 1969. Circadian variations in blood sugar and plasma insulin levels in man. Diabetologia, 5, 397-404.

MARGULES D. L., 1978. Molecular theory of obesity sterility and other behavioral and endocrine problems in genetically obese mice (ob/ob). Neurosci. Behav. Rev., 2, 231-234.

MAY K. K., BEATON J. R., 1966. Metabolic effects of hyperphagia in the hypothalamic-hyperphagic rat. Can. J. Physiol. Pharmacol., 44, 641-650.

MAYER J., THOMAS D. W., 1967. Regulation of food intake and obesity. Science, 156, 328-337.

MICKELSEN O., TAKAHASHI S., CRAIG C., 1955. Experimental obesity. I. Production of obesity in rats by feeding high-fat diets. J. Nutr., 57, 541-554.

NATELSON B. H., BONBRIGHT J. C., 1978. Patterns of eating and drinking in the monkeys when food and water are free and when they are earned. Physiol. Behav., 21, 201-214.

NEMEROFF C. B., BISETTE G., KIZER J. S., 1978. Reduced hypothalamic content of immunoreactive LH-RH activity in genetically obese (ob/ob) mice. Brain Res., 146, 385-387.

NICOLAÏDIS S., MEILE M. J., 1972. Cartographie des lésions hypothalamiques supprimant la réponse alimentaire aux injections intracardiaques du 2-desoxy-D-glucose. J. Physiol. Paris, 65, 151A.

NISHIZAWA Y., BRAY G. A., 1978. Ventromedial hypothalamic lesions and mobilization of fatty acids. J. clin. Invest., 61, 714-722.

OOMURA Y., 1976. Significance of glucose, insulin and free fatty acid of the hypothalamic feeding and satiety neurons, 145-158. In NOVIN D., WYRWICKA N., BRAY G., Hunger-bosic mechanisms and chemical implications. Raven Press, NY.

OTTO W., TAYLOR T. G., YORK D. A., 1976. Glycerol release in vitro from adipose tissue of obese (ob/ob) mice treated with thyroid hormones. J. Endocrinol., 71, 143-155.

PANERAi A. E., OLGIATI V. R., UDESCHINI G., COCCHI D., PECILE A., MÜlleR E. E., 1975. Hyperglycemia and inhibition of insulin secretion by 2-deoxy-D-glucose in rats with hypothalamic lesions. Pharmacol. Res. Communic., 7, 133-141.

PANKSEPP J., NANCE D., 1972. Insulin, glucose and hypothalamic regulation of feeding. Physiol. Behov., 9, 447-451.

PANKSEPP J., POLLACK A., KROST K., MEERER R., RITTER M., 1975. Feeding in response to repeated protamin zinc insulin injections. Physiol. Behav., 14, 487-494.

PECKHAM S. C., ENTENMAN C., CARROL H. W., 1962. The influence of a hypercaloric diet on gross body and adipose tissue composition in the rat. J. Nutr., 77, 187-197.

POWLEY T. L., 1977. The ventromedial hypothalamic syndrome satiety and a cephalic phase hypothesis. Psychol. Rev., 84, 89-126.

POWLEY T. L., OPSAHL C. A., 1974. Ventromedial hypothalamic obesity abolished by subdiaphragmatic vagotomy. Am. J. Physiol., 226, 25-33.

RABIN B. M., 1974. Independence of food intake and obesity following ventromedial hypothalamic lesions in the rat. Physiol. Behav., 13, 769-772.

RIDLEY P. T., BROOKS F. P., 1965. Alterations in gastric secretion following hypothalamic lesions producing hyperphagia. Am. J. Physiol., 209, 319-323.

ROLLS B. J., ROWE E. A., 1977. Dietary obesity : permanent changes in body weight. J. Physiol. London, 272, 2P.

ROTHWELL N. J., STOCK M. J., 1979. A role for brown adipose tissue in diet-induced thermogenesis. Noture, 281, 31-37.

ROWLAND N., ANTELMAN S., 1975. Stress-induced hyperphagia and obesity in rats : a possible model for understanding human obesity. Science, 191, 310-311.

SANDERSON J. D., VANDERWEELE D. A., 1975. Analysis of feeding patterns in normal and vagotomized rabbits. Physiol. Behav., 15, 357-364.

SAWCHENKO P. E., ENG R., GOLD R. M., SIMSON E. L., 1977. Effects of selective subdiaphragmatic vagotomy on knife cuts induced hypothalamic hyperphagia. Proc. 6th int. Conf. Physiol. Food and Fluid Intake, Paris.

SCHEMMEL R., MICKELSEN O., GILL J. L., 1969. Dietary obesity in rats : influence of diet, weight, age and sex on body composition. Am. J. Physiol., 216, 373-379. 
SCHEMMEL R., MICKELSEN O., FISHER L., 1973. Body composition and fat depot weights of rats as influenced by ration-fed dams during lactation and that fed rats after weaning. J. Nutr., 103, 477-487.

SCHEMMEL R., MICKELSEN O., GILL J. L., 1970a. Dietary obesity in rats Body weight and body fat accretion in seven strains of rats. J. Nutr., 100, 1951-1948.

SCHEMMEL R., MICKELSEN O., MOSTOSKY U., 1970b. Influence of body weight, age diet and sex on fat depots in rats. Anat. Rec., 166, 437-466.

SCHLIERF G., DOROW E., 1973. Diurnal patterns of triglyceride-free fatty acids, blood sugar and insulin during carbohydrate induction in man and their modification by nocturnal suppression of lipolysis. J. clin. Invest., 52, 732-740.

SCLAFANI A., GROSSMAN S. P., 1969 . Hyperphagia produced by knife cuts between the medial and lateral hypothalamus in the rat. Physiol. Behav., 4, 533-537.

SCLAFANI A., KLUGE L., 1974. Food motivation and body weight levels in hypothalamic hyperphagic rats : a dual lipostat model of hunger and appetite. J. comp. physiol. Psychol., 86, 28-46.

SCLAFANI A., SPRINGER D., 1976. Dietary obesity in normal adult rats : similarities to hypothalamic and human obesity syndromes. Physiol. Behav., 17, 461-471.

SENSI S., CAPANI F., 1976. Circadian rhythm of insulin-induced hypoglycemia in man. J. clin. Endocr. Metab., 43, 462-465.

SIMSON E. L., GOLD R. M., STANDISH L. J., PELLET P. L., 1977. Axon sparing brain lesioning technique : use of monosodium-L-glutamate and other amino acids. Science, 198, 515-517.

SMITH C. J. V., BRITT D. L., 1971. Obesity in the rat induced by hypothalamic implants of gold thioglucose. Physiol. Behav., 7, 7-10.

STEFFENS A. B., 1969. Plasma insulin content in relation to blood glucose level and meal pattern in the normal and hypothalamic hyperphagic rat. Physiol. Behav., 4, 216-225.

STRAUTZ R. L., 1970. Studies of hereditary obese mice (ob/ob) after implantation of pancreatic islets in Millipore filter capsules. Diabetologia, 6, 306-312.

STRICKER E. M., ROWLAND N., 1978. Hepatic versus, cerebral origin of stimulus for feeding induced by 2-deoxy-D-glucose in rats. J. comp. physiol. Psychol., 92, 126-132.

STRICKER E. M., SWERDLOFF A. F., ZIGMOND M. J., 1978. Intrahypothalamic injections of kainic acid produce feeding and drinking deficits in rats. Brain Res., 158, 470-473.

SWERDLOFF R. S., BATT R. A. L., BRAY G. A., 1976. Reproductive hormonal function in the genetically obese (ob/ob) mouse. Endocrinology, 98, 1359-1364.

SWERDLOFF R. S., PETERSON M., VERA A., BATT R. A. L., HEBER D., BRAY G. A., 1978. The hypothalamic-pituirary axis in genetically obese (ob/ob) mice : response to LRH. Endocrinology, 103, 542-547.

TEITELBAUM P., 1957. Random and food-directed activity in hyperphagic and normal rats. J. comp. physiol. Psychol., 50, 486-490.

THURLBY P. L., TRAYHURN P., 1978. The development of obesity in preweanling (ob/ob) mice. Br. J. Nutr., 39, 397-402.

TRAYHURN P., THURLBY P. L., JAMES W. P. T., 1977. Thermogenic defect in pre-obese ob/ob mice. Nature, 266, 60-62.

WISE R. A., SPINDLER J., DE WIT H., GERBETZ G. J., 1978. Neuroleptic-induced « anhedonia » in rats : pimozide blocks reward quality of food. Science, 201, 262-264.

WOLF L. L., HAINSWORTH F. R., 1977. Temporal patterning of feeding by humming birds. Anim. Behav., 25, 976-989.

YORK D. A., OTTO W., TAYLOR T. G., 1978. Thyroid status of obese (ob/ob) mice and its relationship to adipose tissue metabolism. Comp. Biochem. Physiol., 59, 59-65. 